\title{
Ideologi Di Balik Mitos Dalam Cerpen Akagaeru Karya Shimaki Kensaku: Kajian Semiologi Roland Barthes
}

\author{
Ni Luh Putu Ari Sulatri ${ }^{1)}$, Silvia Damayanti ${ }^{2)}$ \\ ${ }^{1}$ Program Studi Sastra Jepang, Fakultas Ilmu Budaya, Universitas Udayana \\ Jl. Pulau Nias No. 13 Sanglah, Denpasar Timur, Denpasar, Indonesia \\ ${ }^{2}$ Program Studi Sastra Jepang, Fakultas Ilmu Budaya, Universitas Udayana \\ Denpasar, Bali, Indonesia \\ Pos-el: ari sulatri@unud.ac.id
}

\begin{abstract}
Abstrak
Artikel ini mengkaji mengenai ideologi Shimaki Kensaku dalam cerpen Akagaeru.. Kajian ini merupakan penelitian kualitatif yang menerapkan metode hermeneutika untuk menafsirkan makna dari tanda akagaeru. Teori yang digunakan adalah semiologi Roland Barthes dengan model interpretasi tanda dua tingkat. Hasil kajian menunjukan bahwa pada level bahasa penanda akagaeru 'katak merah' mengacu kepada petanda jenis katak endemik Jepang yang berwarna cokelat kemerah-merahan. Petanda akagaeru pada level bahasa menjadi penanda konotasi pada level mitos yang mengacu kepada petanda konotasi 1) kembali kepada ideologi asli Jepang; 2) kegagalan ideologi komunis berkembang di Jepang; 3) penerimaan terhadap penghancuran ideologi komunis di Jepang; dan 4) bertahannya kekaguman terhadap ideologi komunis. Petandapetanda konotasi ini menjadi pembentuk mitos yang terhubung dengan ideologi Shimaki Kensaku, yaitu suichoku tenkō 'tenkō vertikal'
\end{abstract}

Kata kunci: alegori, cerpen Akagaeru, Roland Barthes, semiologi, Shimaki Kensaku

\begin{abstract}
This article examines the ideology of Shimaki Kensaku in the short story Akagaeru. This study is qualitative research by applying the hermeneutic method. This study uses the semiology theory of Roland Barthes with a two-level sign interpretation model. The results of the study show that at the language level, the signifier of akagaeru refers to the signified of reddish-brown type of frog endemic to Japan. The signified at the language level become the signifier of connotation at the myth level which refers to the signified of connotation namely 1) return to the original Japanese ideology; 2) the failure of communist ideology to develop in Japan; 3) acceptance of the destruction of communist ideology in Japan; and 4) persistence of admiration for communist ideology. These signified of connotations form a myth that is connected with Shimaki Kensaku's ideology, namely suichoku tenkō 'vertical tenkō'
\end{abstract}

Keywords: allegory, short story Akagaeru, Roland Barthes, semiology, Shimaki Kensaku

\section{Pendahuluan}

Sastra dan ideologi memiliki hubungan yang erat. Sastra di satu sisi kerap diciptakan untuk memenuhi kebutuhan kelas penguasa dalam masyarakat. Akan tetapi, di sisi lain sifat subversif dari sastra menjadikan karya sastra kerap mempertanyakan, menentang, dan mengungkap kelemahan masyarakat (Moriarty, 2006). Sebagai sebuah istilah ideologi sulit untuk didefinisikan. Ideologi dapat mendistorsi persepsi manusia tentang 
kondisi sosial yang sebenarnya dan menciptakan kesadaran imajiner yang dicapai melalui aparatus ideologis negara untuk melanggengkan ideologi dominan dalam masyarakat. Aparatus ideologis negara ini mencakup semua institusi sosial, seperti pendidikan, politik, hukum, dan agama. Penggunaan bahasa juga digunakan oleh pemegang kekuasaan sebagai senjata untuk menyuntikkan ideologi dominan masyarakat (Althusser, 2008).

Apabila mengacu kepada pemikiran Roland Barthes maka ideologi dapat bersembunyi di balik mitos. Mitos dalam konsep Barthes tidak mengacu kepada mitologi dalam cerita rakyat, tetapi sistem pemaknaan tanda. Mitos merupakan operasi ideologi yang berada pada pemaknaan tanda tingkat kedua atau konotasi. Konotasi pada akhirnya akan mendenotasikan sesuatu dan menjadi mitos. Mitos menampilkan keyakinan tersembunyi yang tidak bersifat alamiah dan memiliki sistem nilai tertentu (Barthes, 1972, hlm. 95).

Ideologi pengarang terkadang tidak ditampilkan secara eksplisit dalam karya sastra yang dihasilkan. Hal ini dipengaruhi oleh beberapa hal, seperti gaya penulisan dari pengarang, untuk menarik minat pembaca, hingga adanya tekanan atau sensor. Di dalam sejarah kesusastraan Jepang, sensor ketat dari pemerintah sepanjang tahun 1930-an hingga tahun 1945 menyebabkan ideologi pengarang disampaikan secara implisit. Hal ini terutama bagi penulis kesusastraan proletar yang berasosiasi dengan Partai Komunis Jepang. Berdasarkan Chian Iji Hō 'Undang-Undang Pelestarian Keamanan Publik', Partai Komunis menjadi partai terlarang di Jepang karena dianggap menyebarkan ideologi subversif. Oleh karena itu, sastrawan yang berafiliasi dengan Partai Komunis Jepang dan gerakan kesusastraan proletar banyak yang ditangkap dan dipaksa melakukan tenkō 'konversi ideologi' untuk meninggalkan keyakinan mereka terhadap komunisme (Lippit, 1992).

Salah satu sastrawan Jepang yang melakukan tenkō adalah Shimaki Kensaku (1903-1945). Agar karya yang dihasilkannya dapat lolos dari sensor, Shimaki menampilkan ideologinya secara terselubung melalui alegori. Teks yang bernuansa subversif politik yang ditulis dalam bentuk alegoris mencapai signifikansinya karena menampilkan perpaduan konseptual yang memungkinkan penulis mengkritik rezim secara tidak langsung karena dapat mengandalkan pembaca untuk menemukan nilai-nilai baru yang sesuai dengan peran tetap alegori sehingga menghasilkan makna baru untuk teks dalam konteks yang berbeda (Hamilton, 2011). 
Di dalam cerpen Akagaeru, Shimaki Kensaku menampilkan alegori melalui figur akagaeru 'katak merah'. Cerpen ini menampilkan tokoh Aku yang pergi untuk beristirahat dan memulihkan dirinya yang sedang sakit dengan menginap di daerah Shuzenji. Di sana tokoh Aku secara tidak sengaja mengamati perilaku katak merah yang mencoba menuju tepi sungai, tetapi alih-alih memilih jalur yang mudah, katak merah memilih jalur yang susah dan terus mencoba ke tepi sungai meskipun dia selalu gagal karena dia memilih jalan dengan arus yang deras. Pada akhir cerita katak merah digambarkan tidak dapat mencapai tepi sungai dan mati (Shimaki, 1970).

Akagaeru bukanlah cerita yang ingin menampilkan kehidupan seekor katak merah, tetapi katak merah menjadi sarana alegoris bagi Shimaki untuk menyampaikan ideologinya di tengah ketatnya sensor pemerintah Jepang pada masa itu. Alegori sangat penting dalam menghadapi penyensoran yang berarti kolokasi cara membaca dan menulis yang lahir dari tekanan sosiopolitik eksternal yang diberikan pada sastra (Gomel, 1995). Alegori mengharuskan pembaca untuk berkolaborasi dengan penulis untuk membuat makna. Artikel ini bertujuan untuk dapat menemukan makna dan mengungkapkan ideologi Shimaki Kensaku dengan menerapkan teori semiologi dari Roland Barthes.

\section{Metode dan Teori}

\subsection{Metode Penelitian}

Fokus utama dalam penelitian ini adalah mengkaji ideologi yang ditampilkan Shimaki Kensaku dalam cerpen Akagaeru. Untuk mengumpulkan data penelitian digunakan metode kajian pustaka mengingat sumber data penelitian adalah karya sastra cetak. Tahapan pengumpulan data diawali dengan membaca sumber data penelitian, yaitu cerpen Akagaeru untuk selanjutnya dicatat data terkait gambaran ideologi Shimaki Kensaku. Data yang telah dicatat selanjutnya dipilah untuk menetapkan data yang digunakan dan data yang tidak digunakan. Pengumpulan data diakhiri dengan tahap klasifikasi data.

Pada tahap analisis data diterapkan metode hermeneutika sehingga dapat ditafsirkan atau dilakukan interpretasi makna dari tanda akagaeru. Teknis analisis diawali dengan analisis makna pada level bahasa (language) dan dilanjutkan dengan analisis pada level mitos (myth) sehingga akhirnya dapat ditafsirkan ideologi yang ditampilkan Shimaki Kensaku dalam cerpen Akagaeru. Untuk menyajikan hasil analisis data digunakan 
metode deskriptif, yaitu dengan cara menyajikan deskripsi fakta yang dilengkapi penjelasan yang memadai. Dalam menyajikan hasil analisis dilakukan secara induktif dengan menguraikan hal-hal yang khusus dan diakhiri dengan simpulan umum (Ratna, 2004: 39-53).

\subsection{Teori}

Ideologi Shimaki Kensaku dalam cerpen Akagaeru yang disajikan secara alegoris maka dibutuhkan teori untuk mengkaji makna dari tanda. Di dalam penelitian ini diterapkan teori semiologi dari Roland Barthes. Barthes mengembangakan sistem interpretasi tanda yang terdiri dari level bahasa dan level mitos. Level bahasa adalah pembacaan tanda tingkat pertama yang mengacu kepada pemikiran Ferdinand de Sausure, tanda dibentuk dari penanda dan petanda. Pembacaan tanda pada level bahasa mengacu kepada makna harfiah yang bersifat denotatif. Makna denotasi menjadi materi dalam pembacaan tanda tingkat kedua atau level mitos. Pada tingkat ini makna denotasi berubah posisi dari petanda menjadi penanda bagi pemaknaan tingkat kedua (Barthes, 1977: 114). Interpretasi tanda pada level mitos mengacu kepada pemikiran Barthes mengenai interpretasi kultural terhadap tanda. Interpretasi tanda tidak hanya berhenti pada pemaknaan denotatif tetapi diperluas hingga pemaknaan konotatif. Hal ini untuk menemukan makna tersembunyi atau yang disebut oleh Barthes dengan mitos. Rangkaian petanda konotasi membentuk mitos (Barthes, 1977: 49). Model interpretasi tanda dua tingkat Barthes digambarkan sebagai berikut

\section{Gambar 1}

Sistem Signifikasi Roland Barthes

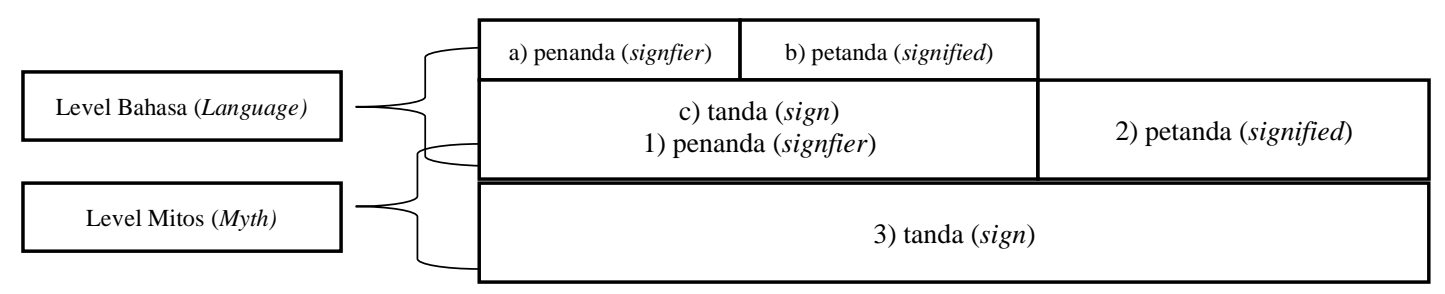

Sumber: (Barthes, 1972, hlm 113)

\section{Kajian Pustaka}


Penelitian mengenai karya Shimaki Kensaku dalam konteks kesusastraan tenkō, diantaranya telah dilakukan oleh Long (2021: 171-184) yang mengkaji karya Shimaki Kensaku yang berjudul Rai 'Kusta' dan Mōmoku 'Kebutaan'. Kajian dari Long menunjukan bahwa Shimaki memasukkan banyak sudut pandang yang berbeda ke dalam narasi serta meninggalkan kesan mendalam tentang eksplorasi diri. Shimaki menciptakan ruang fiktif sehingga dia bisa menyelidiki tema tenkō secara sosial dan linguistik. Orisinalitas Shimaki Kensaku terletak pada cara dia secara tidak sadar dan jelas menggambarkan pengalaman tenkō yang dialaminya dengan cara yang objektif dan universal. Dalam Rai, Shimaki menampilkan wacana yang berorientasi ganda berkisar pada ketegangan antara Shimaki sendiri, tokoh Ōta, dan masalah tenkō. Mōmoku merupakan kelanjutan dari Rai, tetapi juga harus dibaca sebagai eksplorasi Shimaki terhadap shisō 'pikiran' yang menopang hitenkōsha 'orang yang tidak melakukan tenkō, seperti tokoh Koga.

Kajian lainnya terhadap karya Shimaki Kensaku dilakukan oleh Sulatri (2021: 110120) yang mengkaji salah satu cerpen karya Shimaki berjudul Kuroneko. Hasil kajian yang dilakukan menunjukan bahwa refleksi tenkō yang digambarkan Shimaki dalam cerpen Kuroneko tidak menunjukan pertobatan ideologi yang menyebabkan hilangnya kekaguman terhadap komunisme. Tenkō menjadi gambaran penerimaan Shimaki bahwa ideologi komunis tidak cocok diterapkan di Jepang. Tindakan pemerintah Jepang menghancurkan komunisme dianalogikan seperti tindakan seorang ibu yang melindungi keluarganya meskipun harus menghancurkan sesuatu yang dikagumi oleh anggota keluarga yang lain.

Kajian yang telah dilakukan oleh Long dan Sulatri dapat menjadi referensi untuk memahami karakteristik tenkō yang digambarkan Shimaki dalam karya sastra yang dihasilkan. Untuk memperoleh gambaran yang lebih komprehensif mengenai karya sastra tenkō yang dihasilkan Shimaki Kensaku tentu kajian terhadap karyanya yang lain penting untuk dilakukan. Dalam kajian ini, karya sastra Shimaki yang dikaji adalah cerpen $A k$ agaeru dan diharapkan kajian ini dapat memperkaya referensi penelitian terkait karyakarya Shimaki Kensaku dan kesusastraan tenkō Jepang pada umumnya.

\section{Hasil dan Pembahasan}




\subsection{Shimaki Kensaku dan Kesusastraan Tenkō}

Pada bulan Juni 1933, dua pemimpin Partai Komunis Jepang, Sano Manabu dan Nabeyama Sadachika, menerbitkan tenkōsho (pernyataan tenkō). Tenkō merupakan kombinasi dari dua karakter huruf kanji, yaitu “転向 “ yang bermakna 'perubahan arah', tetapi dalam sejarah politik Jepang, tenkō merujuk pada 'konversi ideologis' ratusan aktivis politik dan intelektual komunis (Steinhoff, 1991). Setelah pernyataan tenkō Sano dan Nabeyama, banyak tahanan politik lainnya kemudian mengikuti mengeluarkan pernyataan tenkō (Hoston, 1983).

Fenomena tenkō juga mempengaruhi perkembangan kesusastraan di Jepang, yaitu dengan lahirnya kesusastraan tenkō. Para penulis tenkō pada dasarnya masih penulis Marxis, meskipun mereka telah dipaksa untuk mengingkari aktivitas politik yang berkaitan dengan keyakinan mereka, namun mereka menunjukkan beberapa fleksibilitas ketika menghadapi penindasan negara terhadap kaum Marxis dan komunis Jepang (Honda, 1985: 187-188). Shimaki Kensaku (1903-1945) merupakan salah satu penulis kesusastraan tenkō yang berkembang pada tahun 1930-an.

Shimaki Kensaku, nama aslinya adalah Asakura Kikuo, lahir di kota Sapporo di pulau Hokkaido. Pada tahun 1925, ia masuk Universitas Tohoku di Sendai. Shimaki yang mulai aktif dalam gerakan mahasiswa radikal meninggalkan Sendai setahun kemudian untuk bekerja di koperasi petani di Prefektur Kagawa di Shikoku. Shimaki secara resmi bergabung dengan Partai Komunis Jepang pada tahun 1927 (Miller, 2010: 122-123). Dengan penetapan Undang-Undang Pelestarian Perdamaian (Chian Iji-hō), Partai Komunis dikategorikan sebagai partai terlarang di Jepang karena dianggap menyebarkan ideologi yang dapat mengancam kokutai 'kedaulatan, identitas, dan konstitusi Jepang. Banyak anggota partai, termasuk Shimaki ditangkap di bawah penerapan undang-undang ini. Shimaki ditangkap pada 15 Maret 1928. Saat dihukum di penjara Takamatsu, pihak berwenang mendorong Shimaki untuk membuat pernyataan resmi melepaskan ikatannya dengan Partai Komunis dan berjanji untuk tidak lagi melakukan kegiatan politik. Shimaki membuat pernyataan resmi di pengadilannya pada tahun 1928, tetapi pengadilan tetap menghukumnya karena melanggar Undang-Undang Pelestarian Perdamaian. Dia dijatuhkan hukuman penjara selama empat tahun dan polisi memindahkan Shimaki ke penjara Osaka. Karena penyakit tuberkulosis yang semakin parah, pihak berwenang meringankan hukuman penjaranya pada bulan Maret 1932 (Long, 2021: 171-174). 
Shimaki adalah salah satu yang pertama disebutkan ketika berbicara mengenai kesusastraan tenkō, tetapi ada dua ironi dalam pernyataan ini. Pertama, tenkō yang dilakukan Shimaki muncul pada tahun 1929, empat tahun sebelum istilah tersebut digunakan secara umum. Kesenjangan temporal antara kemunculan historis kata tenkō dan waktu pengalaman Shimaki menunjukkan interpretasi subjektif yang menyebabkan Shimaki dilabeli sebagai penulis tenkō. Poin kedua adalah Shimaki menulis kumpulan cerita pendek pertamanya, Goku 'Penjara' pada tahun 1934 tanpa pengalaman menulis fiksi sebelumnya. Hal ini berbeda dengan sebagian besar penulis tenkō lainnya memiliki pengalaman menulis fiksi sebelum ditangkap. Aktivitas politik Shimaki tampaknya telah mendominasi tahun-tahun sebelum dia dipenjara, namun dua tahun setelah pembebasannya dia mampu menerbitkan serangkaian cerita yang diterima dengan baik oleh kritikus sastra kiri, seperti Moriyama Kei dan Tokunaga Sunao. Karya-karya Shimaki membahas masalah tenkō pada saat tenkō menjadi perhatian utama banyak pembaca sehingga ia dikenal sebagai penulis tenkō meskipun karakter dalam ceritanya sering kali menjadi hitenkōsha 'seseorang yang tetap mempertahankan keyakinan terhadap Komunisme'. Orisinalitas Shimaki Kensaku adalah caranya menggambarkan pengalaman tenkōnya sendiri dengan cara yang objektif dan universal. (Ogasawara, 1965, hlm. 53).

\subsection{Mitos dalam Tanda Akagaeru dan Ideologi Shimaki Kensaku}

Menurut Barthes, mitos adalah suatu tipe wicara yang dibentuk melalui beragam konotasi (Barthes, 1972: 122). Oleh karena itu, menemukan mitos berarti menyusun pemaknaan konotatif terhadap tanda yang terdapat dalam suatu objek. Di dalam kajian ini tanda yang dimaksud dikhususkan pada tanda yang terdapat dalam objek akagaeru. Shimaki menampilkan alegori melalui objek akagaeru untuk menyajikan ideologi secara implisit karena pada masa itu pemerintah memberikan pengawasan terhadap pemikiran yang dipandang subversif (Bix, 1982). Alegori dapat menjadi solusi untuk mengatasi persoalan sensor dalam karya sastra. Penyensoran biasanya ditemukan dalam lima situasi yang berbeda, yaitu 1) penyensoran militer pada masa perang; 2) sensor politik di masa damai; 3) sensor moral; 4) sensor agama; dan 5) sensor perusahaan (Reinelt, 2007). Pada 
kondisi di Jepang, sensor ketat terhadap karya sastra pada tahun 1930-an hingga berakhirnya perang pada tahun 1942 dipengaruhi oleh gabungan fasisme, suatu bentuk khusus dari negara kapitalis modern, dengan militerisme.

Melalui model signifikasi dua tingkat Barthes maka dapat ditemukan mitos dalam tanda akagaeru sehingga akhirnya dapat diketahui ideologi Shimaki Kensaku. Pada level bahasa akan ditemukan makna denotatif dari akagaeru dan pada level mitos akan ditemukan makna konotatif atau ideologi di balik objek akagaeru. Pada signifikasi level bahasa (language) tanda akagaeru dikaji sebagai sebuah penanda (signifier) yang mengacu kepada aspek material dalam wujud citra sensoris akagaeru dan selanjutkan dikaji petanda (signified) yang mengacu konsep mental pada penanda yang dalam hal ini merujuk kepada gagasan denotatif. Berikut akan diuraikan signifikasi level bahasa pada tanda akagaeru

Gambar 2

Signifikasi Level Bahasa pada Tanda Akagaeru

\begin{tabular}{|c|c|c|}
\hline & & b) petanda (signified): \\
\hline $\begin{array}{c}\text { Level Bahasa } \\
\text { (Language) }\end{array}$ & $\begin{array}{l}\text { a) penanda (signfier): } \\
\text { akagaeru 'katak merah' }\end{array}$ & $\begin{array}{l}\text { Binatang berwarna cokelat kemerah- } \\
\text { merahan yang menghuni padang } \\
\text { rumput datar dan sawah. }\end{array}$ \\
\hline
\end{tabular}

Pada signifikasi level bahasa (language), akagaeru 'katak merah' adalah aspek material atau sebuah penanda. Petanda dari akagaeru mengacu kepada konsep mental pada penanda dan merujuk pada gagasan yang bersifat denotatif. Akagaeru meskipun dibentuk dari dua karakter kanji, yaitu “赤蛙” yang secara harfiah berarti 'katak merah' tetapi lebih umum dikenal dengan nama Japanese brown frog dengan nama ilmiah Rana Japonica. Petanda akagaeru mengacu kepada jenis katak yang tergolong dalam genus Rana dan merupakan endemik Jepang. Katak ini berwarna cokelat kemerah-merahan yang menghuni padang rumput datar dan sawah dengan ukuran berkisar antara 3 hingga 7,5 cm (Naturalism, 2003). Berikut adalah visual dari akagaeru. 


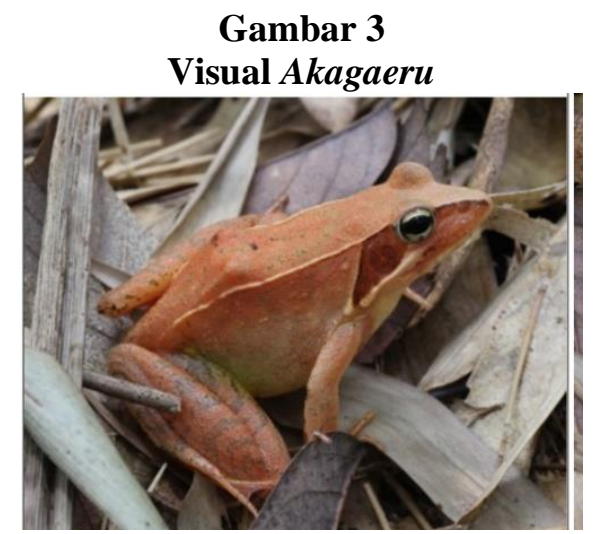

Sumber: http://naturalism-2003.com/kansatsu/animal/amphibian/nihonakagaeru.html

Petanda akagaeru pada signifikasi level bahasa menjadi tanda denotatif yang selanjutnya menjadi penanda konotasi (signifier of connotation) bagi signifikasi level mitos. Pada signifikasi level mitos, selain penanda konotasi yang diperoleh dari tanda denotatif signifikasi level bahasa maka dibutuhkan juga petanda konotasi (signified of connotation). Petanda konotasi akan menuntun dalam penemuan mitos di balik objek akagaeru yang ditampilkan oleh Shimaki Kensaku. Dari penanda konotasi yang mengacu kepada jenis katak berwarna cokelat kemerah-merahan dan pesan linguistik yang disampaikan dalam cerpen Akagaeru akan ditemukan petanda-petanda konotasi terkait yang merupakan penyusun ideologi. Petanda-petanda konotasi bukanlah sesuatu yang bebas nilai karena terkait dengan nilai, sejarah, dan hal-hal lainnya yang terhubung dengan ideologi tertentu.

Untuk menafsirkan petanda konotasi mengenai akagaeru, pertama akan diacu dari makna binatang katak dalam kebudayaan Jepang. Di Jepang, katak yang ditulis dengan karakter kanji “蛙” (kaeru) adalah simbol kesuburan dan keberuntungan. Kata kaeru dengan karakter kanji “帰る” dalam bahasa Jepang berarti 'kembali' karena kesamaan pengucapan kaeru katak banyak dikaitkan dengan benda atau orang yang kembali ke tempat asalnya. Pada zaman dahulu jimat berbentuk katak dibawa oleh orang yang melakukan perjalanan dengan harapan dapat kembali dengan selamat.

Jika mengacu kepada sejarah Jepang maka kaeru yang bermakna 'kembali' erat kaitannya dengan tenkō yang dilakukan oleh Shimaki Kensaku dan para aktivis Komunis lainnya. Honda Shūgo mendefinisikan tenkō dalam tiga klasifikasi, yaitu 1) tenkō yang mengacu pada komunis yang meninggalkan komunisme; 2) tenkō merupakan penolakan pemikiran progresif dan rasional secara umum; dan 3) tenkō mengacu pada fenomena 
perputaran ideologis (Honda, 1985, hlm. 216). Dengan meninggalkan ideologi Komunis yang merupakan ideologi asing, para aktivis Komunis kembali kepada ideologi Jepang. Ideologi politik orisinal yang dikembangkan di Jepang adalah kokutai 'esensi nasional'. Dikembangkan pada masa restorasi Meiji (1866) hingga 1945 untuk menyatukan ideologi dan menyediakan kerangka kerja politik nasional dengan menempatkan sistem monarki konstitusional yang dipinjam dari Barat di bawah Konstitusi Meiji (Brownlee, 2000).

Meskipun menampilkan petanda konotasi kaeru yang selaras dengan makna kaeru dalam budaya Jepang, yaitu "kembali", tetapi Shimaki juga menampilkan petanda konotasi "kegagalan" yang paradoks dengan makna simbol kaeru 'katak' dalam budaya Jepang, yaitu keberuntungan. Di dalam cerpen Akagaeru, katak digambarkan tidak beruntung karena gagal dalam mencapai tujuan dan malah mati dalam usahanya untuk mencapai tujuannya ke tepian sungai. Paradoks ini diperkuat dengan menunjukan bahwa katak dalam cerpen Akagaeru berbeda dengan katak dalam anekdot mengenai Ono no Michikaze, seorang penulis kaligrafri terkenal Jepang dari periode Heian (794-1185), seperti data berikut:

（1）吹く風も俄に冷たくなってて来たし、私は諦めて立ち上った。道風 の雨蛙は飛びつくことに成功したがこの赤蛙はだめだろう ......私は 立って裾のあたりを払った。もう一度、最後に、川の面に眼をやっ た。(Shimaki, 1970).

Fukukaze mo niwaka ni tsumetaku nattete kitashi, watashi wa akiramete tachinobotta. Michikaze no amagaeru wa tobitsuku koto ni seikō shitaga kono akagaeru wa damedarou...... watashi wa tatte suso no atari o haratta. Mōichido, saigo ni, kawanoomo ni me o yatta.

'Angin yang bertiup tiba-tiba menjadi dingin, saya menyerah lalu berdiri. Katak hujan dari cerita Michikaze berhasil melompat, tetapi katak merah ini sepertinya tidak akan bisa... Saya berdiri merapikan sekitar. Sekali lagi, untuk yang terakhir saya melihat ke arah permukaan sungai.'

Data (1) mengambarkan bahwa katak dalam cerpen Akagaeru adalah simbol kegagalan yang berbeda dengan simbol umum yang sudah berkembang di masyarakat Jepang tentang katak sebagai simbol keberuntungan dan keberhasilan, seperti anekdot terkenal antara Ono no Michikaze dan katak. Katak dalam kisah Michikaze sebagai simbol semangat pantang menyerah. Dikisahkan bahwa sebelum menjadi penulis kaligrafi terkenal Ono no Michikaze merasa tidak yakin dengan bakatnya dan ingin menyerah menjadi penulis kaligrafi. Suatu hari ketika Michikaze pergi jalan-jalan, dia melihat seekor katak berusaha melompati pohon willow berulang kali. Michikaze berpikir, katak itu akan gagal 
karena pohon willow jauh, tetapi kemudian angin kebetulan bertiup dan membuat pohon willow bengkok sehingga katak itu berhasil melompat. Michikaze disebutkan berkata bahwa "Saya belum melakukan upaya katak ini" dan mengatakan bahwa dia memiliki kesempatan untuk berusaha kembali menjadi penulis kaligrafi. Katak dalam Michikaze berhasil mencapai tujuannya sebaliknya katak dalam cerpen Akagaeru mengalami kegagalan dan kematian.

Petanda konotasi "kegagalan" berhubungan dengan gagalnya ideologi Komunis berkembang di Jepang. Meskipun para anggota partai Komunis Jepang dan para aktivis komunis sudah berjuang keras agar ideologi tersebut dapat berkembang di Jepang, seperti usaha yang dilakukan oleh akagaeru untuk mencapai tepian sungai, tetapi dengan diberlakukannya Undang-Undang Pelestarian Perdamaian, Partai Komunis menjadi partai terlarang di Jepang dan banyak anggota yang melakukan tenkō. Akan tetapi, ada juga anggota yang lebih memilih kematian dan penjara daripada harus menukar ideologi. Mereka disebut sebagai hitenkōsha 'orang yang tidak melakukan tenkō. Salah satu hitenkōsha adalah Kobayashi Takiji. Dia merupakan anggota Partai Komunis Jepang dan sastrawan proletar yang meninggal tahun 1933 dalam penangkapan. Kobayashi merupakan martir bagi perjuangan komunis dan hal ini menimbulkan kekaguman bagi aktivis Komunis lainnya. Shimaki juga menggambarkan petanda konotasi "kekaguman" atas katak yang mati tanpa rasa takut setelah melakukan perjuangan untuk mencapai tujuannya, seperti data berikut.

(2)心理さえあった。それらは人間の場合のようにこっちに伝わって来 た。明確な目的意志にもとづいて行動してみるものからでなくては あの感じは来ない。ましてや、あの波間に没し去った最後の瞬間に 至つては。そこには刀折れ、矢尽きた感じがあった。力の限り戦っ て来、最後に運命に従順なものの姿があった。そういうものだけが 持つ静けささえあった。(Shimaki, 1970)

Shinri sae atta. Sorera wa ningen no baai no yō ni kotchi ni tsutawatte kita. Meikakuna mokuteki ishi ni motodzuite kōdō shite miru mono karadenakute wa ano kanji wa konai. Mashiteya, ano namima ni bosshi satta saigo no shunkan ni itari tsute wa. Soko ni wa katana ore, ya tsukita kanji ga atta. Chikaranokagiri-sen tte rai, saigo ni unmei ni jüjun'na mono no sugata ga atta. Sō iu mono dake ga motsu shizukesa sae atta.

'Bahkan dalam psikologi. Mereka datang ke sini seperti halnya manusia. Perasaan itu tidak datang kecuali jika itu adalah suatu tindakan berdasarkan tujuan dan niat yang jelas. Belum lagi saat-saat terakhir dia mati di tengah arus. Pada saat itu ada perasaan seakan-akan seluruh alat perangnya rusak atau habis. Dia bertarung sekuat yang ia bisa, lalu akhirnya ia pasrah 
menerima takdirnya. Bahkan ada ketenangan yang dimiliki ketika berada di saat-saat seperti itu.'

Data (2) merupakan wacana yang mengacu kepada kekaguman tokoh Aku akan kematian katak merah setelah berjuang dengan keras untuk mencapai tujuannya. Hal ini seperti kekaguman anggota yang melakukan tenkō terhadap anggota yang memilih menjadi hitenkōsha. Jika merujuk kepada kematian Kobayashi Takiji selain menimbulkan kekaguman, kematiannya Kobayashi juga mengakibatkan para anggota yang melakukan tenkō merasakan perasaan kegagalan ganda yang berasal dari kpenyerahan mereka pada paksaan negara dan kegagalan untuk mengikuti contoh Kobayashi Takiji (Fukuda \& Yano, 1969: 87).

Petanda konotasi berupa "kekaguman" kepada akagaeru, seperti yang ditunjukan pada data (2) juga disertai dengan gejolak batin untuk menerima kenyataan bahwa $a k$ agaeru tersebut telah mati. Jika mengacu kepada tenkō yang dilakukan Shimaki, gejolak batin dalam cerpen Akagaeru serupa dengan keinginan untuk tetap setia kepada ideologi komunis tetapi di sisi lain adanya kebutuhan pada saat itu untuk melakukan tenkō dan menerima kenyataan bahwa ideologi komunis tidak bisa berkembang di Jepang. Hal ini ini digambarkan Shimaki dalam data berikut.

(3) 病気で長く漫つくようになってからも、私は夢のなかで赤蛙に逢っ た。私は夢のなかで色を見るということはめったにない人間だ。し かし波間に没する瞬間の赤蛙の黄色い腹と紅の斑紋とは妖しいばか りに鮮明だった。(Shimaki, 1970)

Byōki de nagaku netsuku yō ni nattekara mo, watashi wa yume no naka de akagaeru ni atta. Watashi wa yume no naka de iro o miru to iu koto wa mettani nai ningenda. Shikashi namima ni bossuru shunkan no akagaeru no kiiroi hara to kurenai no hanmon to wa aya shì bakari ni senmeidatta.

'Bahkan setelah saya tertidur dalam waktu lama karena sakit, saya bertemu dengan katak merah dalam mimpi saya. Saya adalah orang yang jarang melihat warna dalam mimpi tetapi secara misterius perut kuning dengan bintik-bintik merah milik katak merah yang tenggelam dalam ombak terlihat jelas.'

Data (3) menjadi petanda konotasi berupa "kesetiaan" atau rasa kagum yang terus bertahan terhadap akagaeru yang telah mati. Hal ini menggambarkan meskipun telah melakukan tenkō, Shimaki tidak dapat melepaskan kekagumannya kepada ideologi Komunis. Akan tetapi, kekaguman ini juga disertai penerimaan bahwa komunisme telah dihancurkan di Jepang, seperti akagaeru yang telah mati. 
Dari penanda konotasi akagaeru, yaitu jenis katak endemik Jepang yang tergolong dalam genus Rana dengan warna tubuh cokelat kemerah-merahan berukuran antara 3 hingga 7,5 cm yang menghuni padang rumput datar dan sawah dapat diinterpretasikan penanda tersebut terkait dengan petanda konotasi, yaitu 1) kembali kepada ideologi asli Jepang; 2) kegagalan ideologi komunis berkembang di Jepang; 3) penerimaan terhadap penghancuran ideologi komunis di Jepang; dan 4) bertahannya kekaguman terhadap ideologi komunis. Petanda-petanda konotasi ini menjadi pembentuk mitos yang memuat sistem nilai-nilai tertentu (system of values) yang terhubung dengan ideologi pengarang. Sigifikansi pada level mitos terhadap tanda akagaeru ditampilkan sebagai berikut.

\section{Gambar 4}

Signifikasi Level Mitos pada Tanda Akagaeru

\begin{tabular}{|c|l|l|}
\hline $\begin{array}{c}\text { Level Mitos } \\
(\text { Myth })\end{array}$ & $\begin{array}{l}\text { Penanda konotasi } \\
\text { jenis katak endemik Jepang yang } \\
\text { tergolong dalam genus Rana dengan } \\
\text { warna tubuh cokelat kemerah-me- } \\
\text { rahan berukuran antara 3 hingga 7,5 } \\
\text { cm yang menghuni padang rumput } \\
\text { datar dan sawah }\end{array}$ & $\begin{array}{l}\text { Petanda Konotasi } \\
\text { 1) kembali kepada ideologi asli Je- } \\
\text { pang; 2) kegagalan ideologi } \\
\text { komunis berkembang di Jepang; 3) } \\
\text { penerimaan terhadap penghancuran } \\
\text { ideologi komunis di Jepang; dan 4) } \\
\text { bertahannya kekaguman terhadap } \\
\text { ideologi komunis. }\end{array}$ \\
\hline Suichoku Tenkō 'Perubahan Ideologi secara Vertikal \\
\hline
\end{tabular}

Melalui kajian signifikasi dua tingkat Barthes terhadap cerpen Akagaeru dapat digambarkan bahwa ideologi yang ingin ditampilkan Shimaki Kensaku adalah suichoku tenkō atau tenkō vertikal. Hal ini selaras dengan kajian yang telah dilakukan Shinpo (1990: 112) bahwa Shimaki yang mengalah pada penyakit yang diderita serta dibatasi oleh negara sehingga berkomitmen melakukan tenkō vertikal. Suichoku tenkō yang dilakukan Shimaki menunjukan bahwa dia tidak berusaha untuk menggantikan Marxisme dengan ideologi lainnya. Dia juga tidak mengkhianati perasaannya terhadap gerakan proletar dan petani tetapi dia berusaha melalui karya sastranya untuk membantu perjuangan mereka. Namun demikian, Shimaki menemukan bahwa, seiring berjalannya waktu, ia tidak dapat lagi mendukung Partai Komunis Jepang. 


\section{Simpulan}

Ketatnya sensor pemerintah Jepang sepanjang tahun 1930-an hingga tahun 1945 dengan pemberlakuan Chian Iji Hō 'Undang-Undang Pelestarian Keamanan Publik' juga berdampak kepada perkembangan kesusastraan Jepang. Pada masa itu, muncul kesusastraan tenkō yang berkaitan erat dengan peristiwa tenkō yang dilakukan anggota Partai Komunis Jepang dan aktivis gerakan Marxis. Shimaki Kensaku sebagai salah satu sastrawan yang dianggap mewakili kesusastraan tenkō, mengunakan teknik alegori untuk mengatasi ketatnya sensor pemerintah.

Di dalam cerpen Akagaeru, Shimaki menampilkan figur alegoris berupa akagaeru 'katak merah'. Melalui signifikasi dua tingkat dari Roland Barthes dapat diketahui bahwa penanda akagaeru mengacu kepada pertanda jenis katak endemik Jepang yang berwarna cokelat kemerah-merahan. Petanda akagaeru pada signifikasi level bahasa menjadi tanda denotatif yang selanjutnya menjadi penanda konotasi bagi signifikasi level mitos. Dari penanda konotasi akagaeru ditemukan petanda-petanda konotasi yang mendukung maupun menentang dan menjadi paradox simbol kaeru 'katak' dalam budaya Jepang. Petanda-petanda konotasi dalam tanda akagaeru memiliki hubungan erat dengan tenkō yang dilakukan oleh Shimaki Kensaku.

Petanda konotasi akagaeru diindetifikasi dengan kaeru 'kembali' menjadi Jepang dengan meninggalkan ideologi komunis. Kegagalan dari figur akagaeru dalam cerpen untuk mencapai tujuannya ke tepi sungai mengacu kepada petanda konotasi kegagalan ideologi komunis berkembang di Jepang. Petanda konotasi lainnya yang dapat diidentifikasi adalah penerimaan terhadap penghancuran ideologi komunis di Jepang dan bertahannya kekaguman terhadap ideologi komunis. Petanda-petanda konotasi ini menjadi pembentuk mitos yang terhubung dengan ideologi yang ditampilkan Shimaki Kensaku dalam cerpen.

Dengan mengacu kepada petanda-petanda konotasi dari tanda akagaeru dapat disimpulkan bahwa ideologi yang ditampilkan Shimaki Kensaku dalam cerpen Akagaeru adalah suichoku tenkō atau tenkō vertikal. Suichoku tenkō yang dilakukan Shimaki menggambarkan penerimaan bahwa ideologi komunis tidak bisa berkembang di Jepang dan pelepasan diri secara legal dari afiliasi dengan Partai Komunis Jepang. Akan tetapi, di dalam suichoku tenkō juga terkandung makna meskipun Shimaki telah melakukan tenkō tetapi kekagumannya terhadap ideologi komunis tetap bertahan. 


\section{Daftar Pustaka}

Althusser, L. (2008) On Ideology. London: Verso.

Barthes, R. (1972) Mythologies. New York: Noonday Press.

Barthes, R. (1977) Image Music Text. London: Fontana Press.

Bix, H. P. (1982) 'Rethinking "Emperor-System Fascism": Ruptures and Continuities in Modern Japanese History', Critical Asian Studies, 14(2), pp. 2-19. doi: 10.1080/14672715.1982.10412644.

Brownlee, J. S. (2000) 'Four Stages of the Japanese Kokutai [National Essence]', JSAC Conference, October. Available at: http://www.adilegian.com/PDF/brownlee.pdf.

Fukuda, K. and Yano, K. (1969) Shimaki Kensaku: Hito to sakuhin (Shimaki Kensaku: The Man and His Works). Tokyo: Shimizu shoin.

Gomel, E. (1995) 'The poetics of censorship : allegory as form and ideology in the novels of Arkady and Boris Strugatsky', Science Fiction Studies1, 22(65), pp. 87-105.

Hamilton, C. (2011) 'Allegory, blending, and censorship in modern literature', Journal of Literary Semantics, 40(1), pp. 23-42. doi: 10.1515/jlse.2011.002.

Honda, S. (1985) Tenkō bungaku-ron (A Study of tenkō Literature). Tokyo: Miraisha.

Hoston, G. A. (1983) 'Tenko : Marxism \& the National Question in Prewar Japan', Polity, 16(1), pp. 96-118. doi: 10.2307/3234524.

Lippit, N. M. (1992) 'The Dispute Over Socialist Realism In Japan', Journal of South Asian Literature, 27(2), pp. 67-83.

Long, J. E. (2021) 'Crossing The Void Shimaki Kensaku's search for meaning in "Leprosy" and "Blindness"', in Hayter, I., Sipos, G. T., and Williams, M. (eds) Tenkō Cultures of Political Conversion in Transwar Japan. New York \& London: Routledge, pp. 171-184.

Miller, J. S. (2010) The A to $Z$ of Modern Japanese Literature and Theater. Lanhom,Toronto, \& Plymouth: The Scarecrow Press.

Moriarty, M. (2006) 'Ideology and literature', Journal of Political Ideologies, 11(1), pp. 43-60. doi: 10.1080/13569310500395875.

Naturalism (2003) Nihon Akagaeru. Available at: http://naturalism2003.com/kansatsu/animal/amphibian/nihonakagaeru.html (Accessed: 8 September 2020).

Ogasawara, M. (1965) Shimaki Kensaku. Tokyo: Meiji shoin. 
Ratna, N. K. (2004) Teori, Metode, dan Teknik Penelitian Sastra: Dari Strukturalisme hingga Postrukturalisme Perspektif Wacana Sastra. Yogyakarta: Pustaka Pelajar.

Reinelt, J. (2007) 'The limits of censorship', Theatre Research International, 32(1), pp. 3-15. doi: 10.1017/S0307883306002471.

Shimaki, K. (1970) ‘Akagaeru', in Gendainihon bungaku taikei 70 takeda rintarō shimaki kensaku oda sakunosuke dan kazuo-shū. Tokyo: Chikumashobō.

Shinpo, Y. (1990) Shimaki Kensaku: Gi ni uekawaku mono. Tokyo: Riburopoto.

Steinhoff, P. G. (1991) Tenkō: Ideology and Societal Integration in Prewar Japan. New York and London: Garland Publishing.

Sulatri, N. L. P. A. (2021) 'Refleksi Tenkō Shimaki Kensaku dalam Cerpen Kuroneko', in Adnyani, K. E. K. (ed.) Antologi Kajian Linguistik dan Sastra Jepang. Yogyakarta: Deepublish, pp. 110-120. 